ISSN 1810-3030 (Print) 2408-8684 (Online)

\title{
Growth and yield performance of Aloe vera grown in different soil types of Bangladesh
}

\author{
Tanzin Chowdhury ${ }^{1}$, Md Arifur Rahman², Kamrun Nahar ${ }^{2}$, Md. Akhter Hossain Chowdhury ${ }^{2}$ and \\ $\bowtie$ Md. Sirajul Islam Khan ${ }^{1}$
}

${ }^{1}$ Department of Agricultural Chemistry, Sher-e-Bangla Agricultural University, Dhaka-1207, Bangladesh.

${ }^{2}$ Department of Agricultural Chemistry, Bangladesh Agricultural University, Mymensingh-2202, Bangladesh

\begin{tabular}{l}
\hline ARTICLE INFO OPENOACCESS \\
Article history: \\
Received: 29 October 2018 \\
Accepted: 06 December 2018 \\
Published: 31 December 2018 \\
\hline Keywords: \\
Aloe vera; Soil types; Leaf biomass \\
yield and Leaf gel weight
\end{tabular}

Correspondence:

Md. Sirajul Islam Khan

凶: sirajulsau@gmail.com

\begin{abstract}
Plant requires suitable soil for higher yield, quality growth and desired crop productivity that differ with soil characteristics, availability of the nutrient elements and overall soil fertility. Aloe vera, a documented medicative plant, is used for numerous medical and cosmetic applications since very beginning of the civilization. An experiment was conducted in Bangladesh Institute of Nuclear Agriculture (BINA), Mymensingh to find out the most appropriate soil for A. vera cultivation. Seven types of soils viz., acid, calcareous, non-calcareous, charland, saline, peat and acid sulphate were collected from different locations of Bangladesh. Eighteenth month old Aloe vera seedlings were collected from Shomvogonj, Mymensingh and planted during last week of May, 2017 following completely randomized design (CRD) with three replications. Most of the soils were light grey in colour, acidic to neutral in nature and clay to clay loam in texture except non-calcareous and charland soils. Bulk density, particle density and field capacity ranged from $1.23-1.45 \mathrm{~g} \mathrm{~cm}^{-3}, 2.20-2.58 \mathrm{~g} \mathrm{~cm}^{-3}$ and $27.07-30.20 \%$, respectively. The ranges of $\mathrm{pH}$, EC and organic matter contents were 3.8 to $7.8,0.25$ to $14.04 \mathrm{dS} \mathrm{m}^{-1}$ and 0.88 to $16.40 \%$, respectively. The organic matter content was found as low to moderate except peat soil. Total N, exchangeable $\mathrm{K}$, available $\mathrm{P}$ and $\mathrm{S}$ contents ranged from $0.05-0.95 \%, 0.17-0.73 \mathrm{cmol} \mathrm{kg}^{-1}, 3.09-12.10$ and $11.06-735.12 \mu \mathrm{g} \mathrm{g}^{-1}$ soil, respectively. Growth and leaf biomass yield of $A$. vera was significantly influenced by different soil types. The highest plant height, leaf number, leaf area and leaf fresh weight were recorded from the plant grown in non-calcareous soil whereas maximum fresh gel weight, dry leaf weight and yield increase over acid sulphate soil were found from the plant grown in calcareous soil. The highest fresh leaf gel weight $\left(907 \mathrm{~g} \mathrm{plant}^{-1}\right)$ was obtained from the plant grown in calcareous soil which was identical with the gel weight $\left(880 \mathrm{~g} \mathrm{plant}^{-1}\right)$ of the plant grown in acid soil. The yield increase of acid, non-calcareous, charland, saline $1\left(6.32 \mathrm{dS} \mathrm{m}^{-1}\right)$ and saline2 $\left(8.14 \mathrm{dS} \mathrm{m}^{-1}\right)$ soils over acid sulphate soil were $718,712,394,144$ and $86 \%$, respectively. The overall performance of the soils in relation to leaf biomass yield was of the following order: calcareous $\geq$ acid $\geq$ non-calcareous $>$ charland > saline $1\left(6.32 \mathrm{dS} \mathrm{m}^{-1}\right)>$ saline $2\left(8.14 \mathrm{dS} \mathrm{m}^{-1}\right)>$ peat $>$ acid sulphate soil. The results suggest that farmers could be advised to grow $A$. vera either in calcareous or acid soils of Bangladesh. Since calcareous and non-calcareous soils are mostly used for growing cereals, pulses, cash crop like sugarcane, fruits etc., acid soil could be used for cultivating this important medicinal crop considering the socioeconomic conditions of the country.
\end{abstract}

\section{Copyright:}

(C2018 by authors and BAURES. This work is licensed under the Creative Commons Attribution International License (CC By 4.0).

\section{Introduction}

Aloe vera, a multifunctional and miracle plant, used as medicinal and ornamental purposes, healthy food ingredient as well as the materials for cosmetic industries. It belongs to the family Alliaceae and genus Aloe containing about 420 species (Dange et al., 2000). This perennial succulent plant has the ability to develop water storage tissue in the leaves to survive in dry conditions with low or erratic rainfall (Kumar and Yadav, 2014). The leaves of this plant contain fat compounds, carbohydrates, proteins, lipids, and 18 essential amino acids, vitamins (e.g., A, C, E, vitamin B12, folic acid), minerals, glycoprotein, Cglucosylchromone, anthraquinones, emodin, salicylic acid and various kinds of enzymes (Hamman, 2008; Surjushe et al., 2008). It also contains secondary metabolites like alkaloids, aloins, lectins, lignin, saponins, tannins, phenolic and glukomannan (Boudreau and Beland, 2006; Darini et al., 2013). The cultivation of A. vera has gained commercial importance for medicinal products and cosmetics processing. Its cultivation is expanding rapidly as it provides quick and regular income to the farmers (Moorthy and Malliga, 2012). Aloe gel possesses important biological properties such as antimicrobial (Bashir et al., 2011), anticancer (Naveena et al., 2011), antioxidant (Miladi and Damak, 2008), antidiabetic (Jones, 2007), antiulcer (Borra et al., 2011), hepatoprotective (Chandan et al., 2007), immunomodulatory (Atul et al., 2011) and many more medicinal activities. The gel of Aloe leaves is also associated with many health benefits as it contains polysaccharides (Josias, 2008). Yusuf et al. (2004) reported that the plant has the potential of secreting gastric acid on the gastric mucosal injury. Okonkwo et 
al. (2009) reported that the gel has also the potential of controlling body rashes, mouth odour, running nose, itching, soar throat and such veneral diseases as gonorrhoea, staphylococcus and vaginal discharge when combined with some African medicinal leaves.

Different biotic and abiotic factors may affect crop production (Orcutt and Nilsen, 2000). Soil provides most of our necessities through the plant and animal communities which develop on it (Garg and Kumar, 2012). Soil ensures physical support for plant growth and development by supplying necessary water and nutrient elements. Soil types, soil nutrient status, and fertilizer management usually influence the growth, yield and quality of a plant species, and their suitability is the prerequisite for higher yield and better quality crops (Hossain and Ishimine, 2005; Akamine et al., 2007; Chowdhury et al., 2008; Hossain et al., 2011; Islam et al., 2011). Soil type is an important abiotic factor that might affect plant growth through controlling the nutrient supply, altering the function of plant roots and soil-borne microbes like root endophytic fungi, mycorrhizal fungi and rhizobia (Chiarini et al., 1998; Egamberdiyeva, 2007; Latour, 1996; Pineda, 2010). Crop productivity varies with the contents and different combinations of nutrient elements, $\mathrm{pH}, \mathrm{EC}$ and organic matter present in soil (Broadley et al., 2012; Hawkesford et al., 2012). Different soils might have various effects on the function of plant growth-promoting microorganisms (PGPMs), which could promote plant growth (Sripontan et al., 2014). For functioning through the soils, nutrients might be the most important factor to affect the growth of plants and their biochemical constituents (Altieri and Nicholls, 2003; Mevi-Schütz et al., 2003). The soil nutritional elements required for the growth are not only the important sources of materials for building up the structures of plant tissues, but also are actively involved in the metabolic activities within plants (Al-Humaid, 2005). Soil organic carbon is also a crucial parameter for soil fertility as it enhances soil physical, chemical and biological properties (Lützow et al., 2006; Birkhofer et al., 2008). To develop management practices for higher yield and good quality of plant product, investigation on different growth parameters of the plant is critical by using different types of local soils (Hossain and Ishimine, 2005). The quality of medicinal herb like A. vera is the comprehensive indicator reflecting certain cultivation technologies and ecological conditions in different Bangladeshi soils. It is a semi subtropical plant that can be grown easily like other vegetable crops (McKeown, 1987). Aloe vera grows well in all kinds of soils but well drained soil rich in organic matter is preferable (Kumar and Yadav, 2014) because of their their sensitivity to water stagnant conditions (Manvitha and Bidya, 2014). As an agrobased country, Bangladesh could easily introduce $A$. vera as a commercial crop like others and can be cultivated in its relatively high land and homestead area as it grows well in open space with proper drainage. Being a new crop, A. vera is needed to be domesticated in Bangladesh, a package regarding the soil and cultivation aspects, to standardize under different agro climatic conditions to boost up its cultivation. To the best of our knowledge, till now no detailed study has yet been conducted to evaluate the effects of different soil types on the growth and leaf yield of A. vera in Bangladesh. So, it is necessary to select better soil(s) for the cultivation of this valuable medicinal plant. In this study, based on the characteristics of the natural distribution pattern of soils, seven representative soil types of Bangladesh with different physiochemical properties were selected for conducting the controlled experiments on the cultivation of $A$. vera, aiming to study the correlations of the soil factors with its growth, and leaf biomass yield.

\section{Materials and Methods}

The experiment was conducted in the net house of Bangladesh Institute of Nuclear Agriculture, Mymensingh during May to August 2017. Seven types of soils namely acid, calcareous, non-calcareous, charland, saline, peat and acid sulphate soils were collected from different locations of six districts of Bangladesh viz., Fulbaria (Mymensingh), Sadar (Natore), Agronomy Field Laboratory of Bangladesh Agricultural University, Mymensingh, Melandoh (Jamalpur), Botiaghata (Khulna), Kotalipara (Gopalganj) and Pekua (Cox's Bazar), respectively during the month of February-April, 2017 for A. vera cultivation. Eighteen months old $A$. vera seedlings were collected from Shomvogonj, Mymensingh and used for the experiment following CRD with three replications. For the present investigations, approximately $40 \mathrm{~kg}$ soils from each location were collected from $0-15 \mathrm{~cm}$ depth of selected fallow land to screen out the best soil for Aloe vera cultivation. The soils were separately put in to plastic bags and carried to the laboratory with proper tagging. The collected soil samples were made free from plant residues and other extraneous materials; then air dried, ground and sieved through a $2 \mathrm{~mm}$ sieve. The whole process was done several times until adequate amount of soil was prepared for the experiment. Eight $\mathrm{kg}$ processed soil was taken in each earthen pot of $23 \mathrm{~cm}$ in height with $30 \mathrm{~cm}$ diameter at the top and $18 \mathrm{~cm}$ diameter at the bottom. Approximately $500 \mathrm{~g}$ sieved soil from each source was preserved in a polythene bag for physical and chemical analyses. The soil was mixed thoroughly with well decomposed dry cow dung (CD), urea, TSP, MoP and gypsum @500.0, 2.0, 0.9, 1.2 and $0.75 \mathrm{~g} \mathrm{pot}^{-1}$, respectively in each pot for normal growth and development of $A$. vera seedlings. The total nutrient concentrations of $\mathrm{CD}$ used in the experiments were $\mathrm{OC}$, $\mathrm{N}, \mathrm{P}, \mathrm{K}, \mathrm{S}, \mathrm{Ca}$ and $\mathrm{Mg}$ as 24.03, 1.05, 0.35, 0.45, 0.24, 0.16 and $0.015 \%$ respectively. Distilled water was added in each pot, covered with polyethylene and kept for one week before transplanting. Intercultural operations like irrigation, soil loosening, weeding, insect pest control etc. were done as and when necessary. The crop was destructively harvested at 120 days after planting (DAP), cleaned, oven dried at $60^{\circ} \mathrm{C}$ for 72 hours. Plant height, branches plant ${ }^{-1}$, leaves plant ${ }^{-1}$, leaf area plant ${ }^{-1}$, fresh and dry leaf weight of stevia were studied. Analysis of 
variance (ANOVA) was done following the principal of F-statistics and the mean values were separated by Duncan's Multiple Range Test (Gomez and Gomez, 1984).

\section{Results and Discussion}

Soils of different types affect crop production according to their capability as a nutrient supplier based on plant requirement. Incorporation of $A$. vera into agricultural production systems depends upon details information regarding the plant, suitability of soil, its agronomic potentiality and nutritional requirements. Seven different soils types were selected to find out the most suitable soil for A. vera cultivation in Bangladesh.

\section{Physico-chemical properties of soils}

The results of the physical and chemical properties of seven soils used in the study have been presented in Table 1. Colour, texture, $\mathrm{pH}$ and $\mathrm{EC}$ values, organic matter, total $\mathrm{N}$, exchangeable $\mathrm{K}$, available $\mathrm{P}$ and $\mathrm{S}$ concentrations in different soil types varied considerably. Majority of the soils were light grey in colour except acid and peat soils which were reddish and blackish, respectively. Most of the soils were clay to clay loam in texture except non-calcareous and charland soils which were sandy clay loam to loam. Bulk density, particle density and field capacity varied with respect to soils and ranged from $1.23-1.45 \mathrm{~g} \mathrm{~cm}^{-3}, 2.20-2.58 \mathrm{~g} \mathrm{~cm}^{-3}$ and $27.07-30.20 \%$, respectively. Non-calcareous soil had the highest particle density and bulk density whereas the highest field capacity was found in saline 2 soil.
The chemical properties of soils also varied across the soil types. The range of $\mathrm{pH}, \mathrm{EC}$ and organic matter content was found as $3.80-7.80,0.25-14.04 \mathrm{dS} \mathrm{m}^{-1}$ and $0.88-16.40 \%$, respectively. The soils were acidic to slightly alkaline which should render them suitable for growing crops except acid sulphate soil (pH 3.8). The highest pH (7.8) and EC (14.04 $\mathrm{dS} \mathrm{m}^{-1}$ ) were recorded from saline2 and acid sulphate soils, respectively. Among the chemical parameters, the contents of total $\mathrm{N}$, exchangeable $\mathrm{K}$, and available $\mathrm{P}$ and $\mathrm{S}$ concentrations ranged from $0.05-0.95 \%, 0.17-0.73 \mathrm{cmol}$ $\mathrm{kg}^{-1}, 3.09-12.10$ and $11.06-735.12 \mu \mathrm{g} \mathrm{g}^{-1}$ soil, respectively. Peat soil had the highest organic matter $(16.40 \%), \mathrm{N}(0.95$ $\%)$ and exchangeable $\mathrm{K}\left(0.73 \mathrm{cmol} \mathrm{kg} \mathrm{kg}^{-1}\right)$ contents. Conversely, the charland soil exhibited the lowest organic matter $(0.88 \%)$ and $\mathrm{N}(0.05 \%)$ contents. Available P content $(12.1 \%)$ was highest in non-calcareous soil. Acid soil had generally intermediate values of the studied properties (Table 1).

Different types of soil have quite different physicochemical properties, which have substantial effects on the growth, development and the active constituents of medicinal plants ( $\mathrm{Li}$ and Xiao, 2012). Thus, various plants have different demands for appropriate type(s) of soil. For instance, Liu et al. (2007) reported that the types and texture of soil were closely related to the growth and development of medicinal plants and loam soil was relatively ideal type for the cultivation of root/stem-types of medicinal plants.

Table 1. Physico-chemical properties of different soil types used for Aloe vera cultivation

\begin{tabular}{|c|c|c|c|c|c|c|c|c|}
\hline \multirow[t]{2}{*}{ Parameters } & \multicolumn{8}{|c|}{ Soil types } \\
\hline & Acid & Calcareous & Non calcareous & Charland & Saline1 & Saline2 & Peat & $\begin{array}{c}\text { Acid } \\
\text { sulphate }\end{array}$ \\
\hline Colour & Reddish & Light grey & Light grey & Light grey & Light grey & Light grey & Blackish & Light grey \\
\hline Texture & Clay & Clay loam & Sandy clay loam & Loam & Clay & Cay & Clay loam & Clay \\
\hline Bulk density $\left(\mathrm{g} \mathrm{cm}^{-3}\right)$ & 1.23 & 1.42 & 1.45 & 1.44 & 1.25 & 1.24 & 1.41 & 1.28 \\
\hline Particle density $\left(\mathrm{g} \mathrm{cm}^{-3}\right)$ & 2.25 & 2.51 & 2.58 & 2.54 & 2.23 & 2.20 & 2.52 & 2.24 \\
\hline Field capacity $(\%)$ & 29.86 & 28.12 & 27.07 & 27.15 & 29.72 & 30.20 & 28.34 & 29.55 \\
\hline $\mathrm{pH}$ & 5.2 & 7.5 & 6.7 & 7.0 & 7.5 & 7.8 & 5.7 & 3.8 \\
\hline $\mathrm{EC}\left(\mathrm{dS} \mathrm{m} \mathrm{m}^{-1}\right)$ & 0.25 & 1.26 & 0.68 & 0.61 & 4.41 & 6.10 & 4.09 & 14.04 \\
\hline $\mathrm{OM}(\%)$ & 1.58 & 1.40 & 1.83 & 0.88 & 1.97 & 2.51 & 16.40 & 2.45 \\
\hline Total N (\%) & 0.09 & 0.07 & 0.12 & 0.05 & 0.11 & 0.15 & 0.95 & 0.14 \\
\hline Avail. $\mathrm{P}\left(\mu \mathrm{g} \mathrm{g}^{-1}\right)$ & 3.09 & 4.86 & 12.1 & 6.91 & 5.89 & 6.90 & 3.12 & 4.72 \\
\hline Exch. K $\left(\mathrm{cmol} \mathrm{kg}^{-1}\right)$ & 0.20 & 0.19 & 0.17 & 0.18 & 0.41 & 0.44 & 0.73 & 0.22 \\
\hline Avail. $\mathrm{S}\left(\mu \mathrm{g} \mathrm{g}^{-1}\right)$ & 11.80 & 15.78 & 11.06 & 19.50 & 35.20 & 43.47 & 641.40 & 735.12 \\
\hline
\end{tabular}

Avail. $=$ Available, Exch. $=$ Exchangeable, Saline1 $=6.32 \mathrm{dS} \mathrm{m}^{-1}$ and Saline $2=8.14 \mathrm{dS} \mathrm{m}^{-1}$.

Effects of different soil types on the growth and leaf biomass yield of $A$. vera

\section{Plant height}

Data on the effects of different soil types on plant height of A. vera have been presented in Table 2. Soil types significantly influenced the height of $A$. vera plant at harvest. The highest plant height $(44.03 \mathrm{~cm})$ was recorded from the plant grown in non-calcareous soil which was statistically identical with those plants grown in acid soil $(40.37 \mathrm{~cm})$, calcareous soil $(41.73 \mathrm{~cm})$ and charland soil $(39.53 \mathrm{~cm})$ but significantly different from the plants grown in saline, peat and acid sulphate soils. Saline and peat soils produced statistically similar heighted plants. The lowest plant height $(23.17 \mathrm{~cm})$ was recorded from the plant grown in acid sulphate soil. Similar findings were previously reported by Zaman et al. (2015) in case of stevia, who reported the tallest plant from non-calcareous soil and shortest plant from acid sulphate soil.

\section{Leaf number}

The number of leaves plant $^{-1}$ at harvest differed significantly due to the influence of different soil types of Bangladesh (Table 2). The highest number of leaves plant ${ }^{-1}$ 
(12.67) was counted from the plant grown in noncalcareous soil which was identical with the number of leaves of the plant grown in acid (11.33) and calcareous (10.89) soils. The plants of calcareous (10.89) and charland (8.33) soils produced identical number of leaves. Saline soils of 6.32 and $8.14 \mathrm{dS} \mathrm{m}^{-1}$ also produced identical number of leaves plant ${ }^{-1}$. The lowest number of leaves (4.00) was harvested from the plant grown in peat soil which was statistically identical with those plants grown in saline and acid sulphate soils (4.33). Better performance of non-calcareous and calcareous soils might be due to their moderate $\mathrm{pH}$, less water holding capacity, good soil texture and higher nutrient contents compared to other soils. Similarly acid soil having $\mathrm{pH}$ less than 7 , strongly acid in reaction with moderate status of organic matter, low moisture holding capacity (BARC, 2005) could the reasons for obtaining better yield. This finding was in line with Zaman et al. (2015) who observed the highest leaf number of stevia from non-calcareous soil and the lowest from acid sulphate soil.

Table 2. Growth and leaf biomass yield of Aloe vera grown in different soil types of Bangladesh

\begin{tabular}{|c|c|c|c|c|}
\hline Soil types & $\begin{array}{l}\text { Plant height } \\
(\mathrm{cm})\end{array}$ & $\begin{array}{c}\text { Leaves } \\
\text { plant }^{-1} \text { (no.) }\end{array}$ & $\begin{array}{c}\text { Mean leaf area } \\
\text { plant }^{-1}\left(\mathrm{~cm}^{2}\right)\end{array}$ & $\begin{array}{c}\text { Dry leaf weight } \\
\left(\mathrm{g}_{\text {plant }}^{-1}\right)\end{array}$ \\
\hline Acid soil & $40.37 \pm 4.50 \mathrm{a}$ & $11.33 \pm 0.58 \mathrm{a}$ & $245.97 \pm 22.9 \mathrm{a}$ & $133.4 \pm 5.4 \mathrm{a}$ \\
\hline Calcareous soil & $41.73 \pm 3.82 \mathrm{a}$ & $10.89 \pm 1.15 \mathrm{ab}$ & $255.57 \pm 3.3 a$ & $136.0 \pm 6.1 \mathrm{a}$ \\
\hline Non-calcareous soil & $44.03 \pm 4.58 \mathrm{a}$ & $12.67 \pm 2.52 \mathrm{a}$ & $262.70 \pm 18.3 \mathrm{a}$ & $132.3 \pm 13.1 \mathrm{a}$ \\
\hline Charland soil & $39.53 \pm 3.55 \mathrm{a}$ & $8.33 \pm 1.53 b$ & $200.67 \pm 16.4 b$ & $80.5 \pm 10.0 \mathrm{~b}$ \\
\hline Saline1 soil & $30.73 \pm 3.69 b$ & $5.67 \pm 1.53 \mathrm{c}$ & $181.89 \pm 12.3 b c$ & $39.7 \pm 2.0 \mathrm{c}$ \\
\hline Saline2 soil & $28.37 \pm 3.21 b c$ & $5.00 \pm 1.00 \mathrm{c}$ & $170.21 \pm 15.6 \mathrm{~cd}$ & $30.3 \pm 0.9 \mathrm{c}$ \\
\hline Peat soil & $25.86 \pm 2.65 b c$ & $4.00 \pm 1.00 \mathrm{c}$ & $166.54 \pm 14.5 \mathrm{~cd}$ & $18.3 \pm 3.0 \mathrm{~d}$ \\
\hline Acid Sulphate soil & $23.17 \pm 2.42 \mathrm{c}$ & $4.33 \pm 1.53 \mathrm{c}$ & $144.38 \pm 8.3 d$ & $16.3 \pm 0.8 \mathrm{~d}$ \\
\hline $\mathrm{CV} \%$ & 10.60 & 19.01 & 7.40 & 9.06 \\
\hline $\mathrm{LSD}_{0.05}$ & $6.28 * *$ & $2.52 * *$ & $26.06 * *$ & $11.51 * *$ \\
\hline
\end{tabular}

Means within the same column followed by different letter(s) were significantly different according to DMRT (**P<0.01), Values are mean $\pm \mathrm{SD}$; Saline1 $=6.32 \mathrm{dS} \mathrm{m}^{-1}$, Saline $2=8.14 \mathrm{dS} \mathrm{m}^{-1}$. LSD $=$ Least significant difference and CV $=$ Coefficient of variance

\section{Leaf area}

The data pertaining to leaf area plant $^{-1}$ at harvest as influenced by different soil types of Bangladesh have been presented in Table 2. Mean leaf area plant $^{-1}$ was significantly affected by different soil types. Maximum leaf area $\left(262.70 \mathrm{~cm}^{2}\right)$ was measured from the plant grown in non-calcareous soil, which was identical with the leaf area of the plants grown in acid $\left(245.97 \mathrm{~cm}^{2}\right)$ and calcareous $\left(255.57 \mathrm{~cm}^{2}\right)$ soils. Charland $\left(200.67 \mathrm{~cm}^{2}\right)$ and saline1 $\left(181.89 \mathrm{~cm}^{2}\right)$ soils produced identical leaf area plant $^{-1}$. Saline soil at all levels and peat soil also produced identical leaf areas plant ${ }^{-1}$. The minimum leaf area $\left(144.38 \mathrm{~cm}^{2}\right)$ was obtained from the plant grown in acid sulphate soil, which was identical with the plants grown in saline2 $\left(170.21 \mathrm{~cm}^{2}\right)$ and peat soils (166.54 $\mathrm{cm}^{2}$ ). These findings were in good agreement with the results reported by Khanom et al. (2008) and Zaman et al. (2015) for stevia.

\section{Fresh leaf weight}

Soil types had significant effects on leaf fresh weight of A. vera (Fig. 1). The highest leaf fresh weight was obtained from the plant grown in non-calcareous soil (1948 g plant $^{-1}$ ), which was statistically non-significant with the fresh weight of the plant grown in acid (1768 g plant $^{-1}$ ) and calcareous (1896 g plant $^{-1}$ ) soils.

The lowest fresh weight was obtained from the plant grown in acid sulphate soil (233 $\left.\mathrm{g} \mathrm{plant}^{-1}\right)$, which was identical with the fresh weight of the plant grown in peat soil $\left(262 \mathrm{~g} \mathrm{plant}^{-1}\right)$. Too low $\mathrm{pH}$ of acid sulphate soil which in turn reduces nutrient availability and very high organic matter content of peat soil causing nutrient toxicity could be the prime reason of getting lowest yield of A. vera. Soil provides physical support to plant as well as supplies necessary water and nutrient elements for plant growth and development. Plant growth basically depends on the physical, chemical and biological properties of soil. Khanom et al. (2008) cultivated stevia in four different soils of Bangladesh viz. calcareous, non-calcareous, acid and saline soils and reported that non-calcareous soil was the best performer followed by acid soil for the growth and leaf yield of stevia. The result coincided with the present study. Similar results were reported by Zaman et al. (2015) for the fresh weight of stevia leaf.

\section{Fresh leaf gel weight}

A statistically significant variation was noticed in terms of fresh leaf gel weight of $A$. vera due to differences in soil types (Fig. 2). The highest fresh leaf gel weight $(907$ $\mathrm{g}$ plant $^{-1}$ ) was obtained from the plant grown in calcareous soil, which was identical with the gel weight $\left(880 \mathrm{~g} \mathrm{plant}^{-1}\right)$ of the plant grown in acid soil. Better performance of acid soil might be due to having $\mathrm{pH}$ less than 7 , strongly acid in reaction with moderate status of organic matter, low moisture holding capacity (BARC, 2005). The fresh gel weights of the plants grown in acid (880 $\mathrm{g} \mathrm{plant}^{-1}$ ) and non-calcareous (859 $\mathrm{g} \mathrm{plant}^{-1}$ ) soils were also identical. The lowest fresh gel weight was obtained from the plant grown in peat soil (192 $\mathrm{g}$ plant $^{-1}$ ), which was not supported by the result reported by Rahi et al. (2013) on A. vera grown in sodic soil. Very poor performance of peat soil might be due to its high organic matter content $(>20 \%)$ and water saturated 
environment (Khan et al., 2008). The poor performance of acid sulphate soil mainly could be due to its very low $\mathrm{pH}$ (3.9). The performance variation of different soils for fresh leaf weight might be due the physical and chemical properties of the soils under investigation.

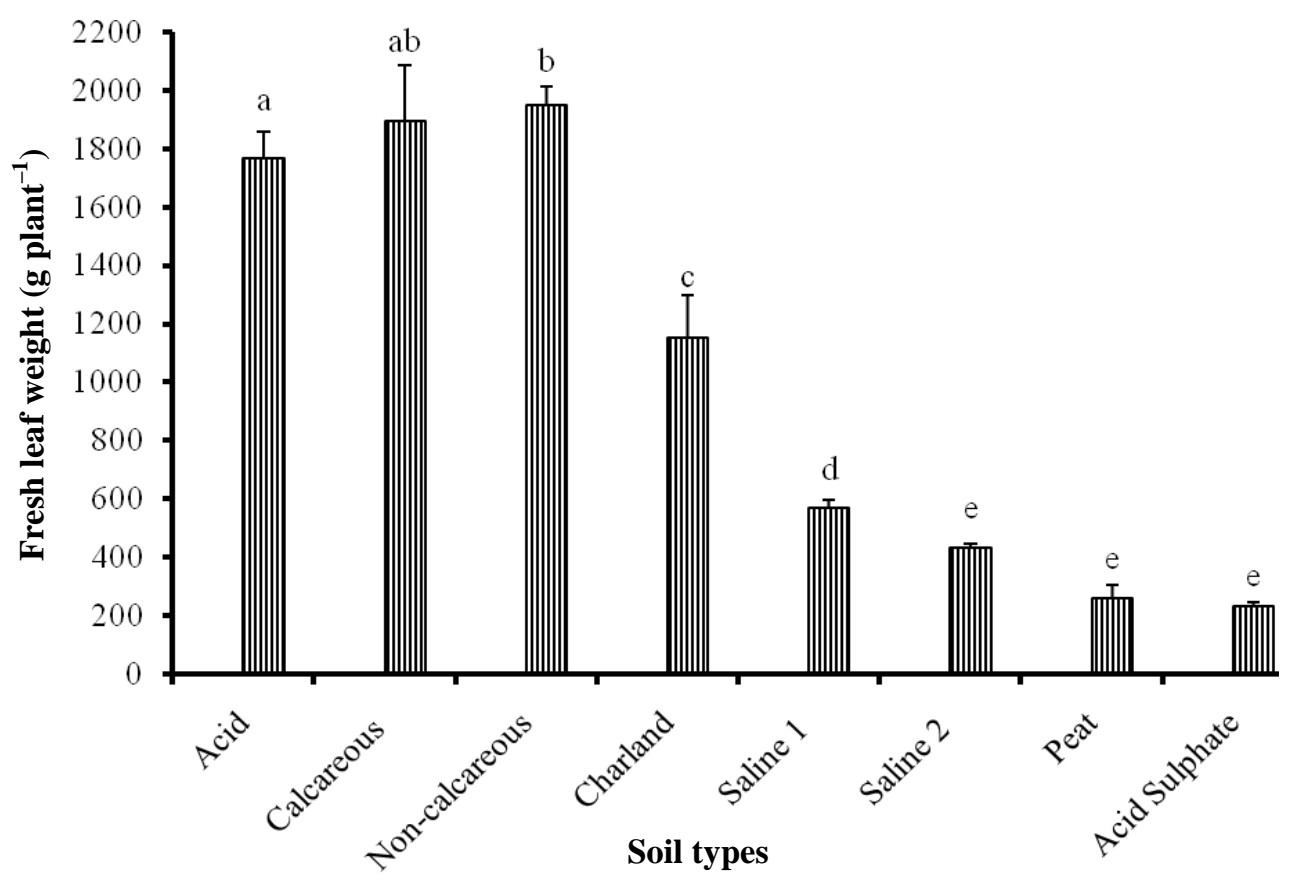

Fig. 1. Fresh leaf weight of Aloe vera grown in different soil types of Bangladesh $\left(\right.$ Saline1 $=6.32 \mathrm{dS} \mathrm{m}^{-1}$, Saline2 $=8.14 \mathrm{dS} \mathrm{m}^{-1}$ )

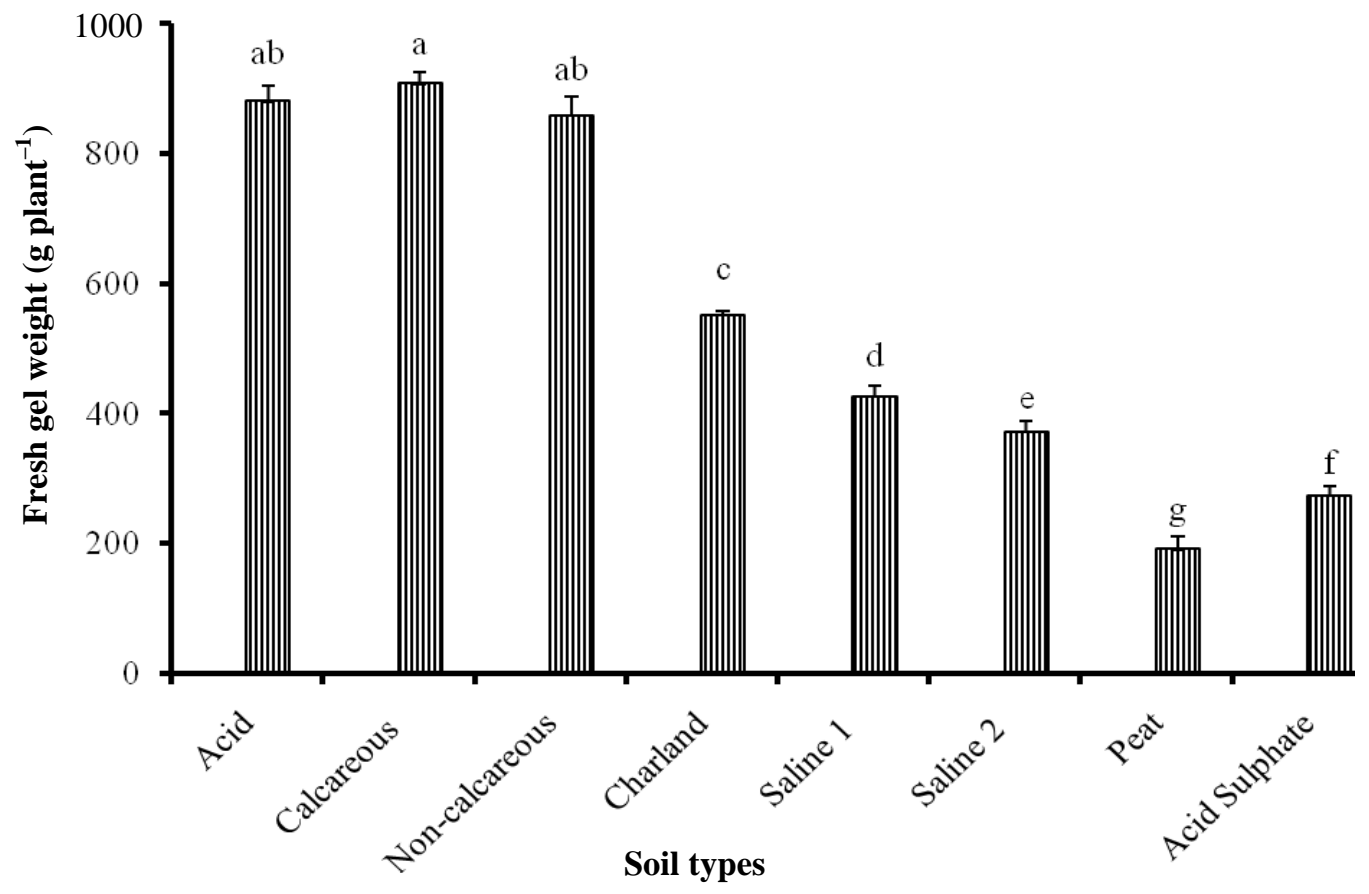

Fig. 2. Fresh gel weight of Aloe vera grown in different soil types of Bangladesh (Saline1 $=6.32 \mathrm{dS} \mathrm{m}^{-1}$ and Saline $2=8.14 \mathrm{dS} \mathrm{m}^{-1}$ ) 
In addition, balanced $\mathrm{P}, \mathrm{K}, \mathrm{S}$, and $\mathrm{pH}$ and $\mathrm{EC}$ probably made better combination in calcareous soil for better gel yield of Aloe vera, as compared to the other soils (Table 1 and Fig. 2). Similar findings were also reported using balanced NPKS to obtain higher biomass production (Akamine et al., 2007; Hossain et al., 2012; Ohshiro et al., 2016)

\section{Dry leaf weight}

The dry weight of $A$. vera leaves varied significantly due to the differences in soil types (Table 2). The highest leaf dry weight $\left(136.0 \mathrm{~g}\right.$ plant $\left.^{-1}\right)$ was obtained from the plant grown in calcareous soil which was identical with the dry weights of the plants grown in acid $(133.4 \mathrm{~g}$ plant $^{-1}$ ) and non-calcareous (132.3 $\left.\mathrm{g} \mathrm{plant}^{-1}\right)$ soils. The dry weight of the plant grown in charland soil was 80.5 $\mathrm{g}$ plant $^{-1}$. The lowest dry weight $\left(16.3 \mathrm{~g}\right.$ plant $\left.^{-1}\right)$ was obtained from the plant grown in acid sulphate soil which was identical with the dry weight $\left(18.3 \mathrm{~g} \mathrm{plant}^{-1}\right)$ of the plant grown in peat soil. The dry leaf yield of other soils increase over acid sulphate soil ranged between $12 \%$ for the plant of peat soil to $734 \%$ for the plant of calcareous soil.

The yield increase of the plants grown in acid, noncalcareous, charland, saline1 and saline 2 soils were 718, $712,394,144$ and $86 \%$, respectively. Dry leaf yield of $A$. vera grown in different soils of Bangladesh was of the following order: calcareous $\geq$ acid $\geq$ non-calcareous > charland > saline1 $\left(6.32 \mathrm{dSm}^{-1}\right)>$ saline $2\left(8.14 \mathrm{dSm}^{-1}\right)$ $>$ peat >acid sulphate soils. The performance variation of different soils for A. vera cultivation might be due the physical and chemical properties of the soils under investigation. Among the properties, $\mathrm{pH}$, organic matter content, salinity, nutrient contents and their availability could be the prime factors controlling the growth and yield of any crop. Very poor performance of peat soil might be due to its high organic matter content $(>20 \%)$ and water saturated environment (Khan et al., 2008) occupied up to $40 \mathrm{~cm}$ depth having major constituent of dark brown muck. The poorest performance of acid sulphate soil mainly could be due to its very low $\mathrm{pH}$ (3.9).

Acid sulphate soil contains iron sulphides. When sea level rise inundates land, $\mathrm{SO}_{4}{ }^{2-}$ in the sea water is mixed with land sediments containing oxides. The resulting chemical reaction produces sulphuric acid for which the name acid sulphate soils (Khan et al., 2008) stand. The potential of the acid sulphate soils for crop production is severely limited by some environmental factors like saline tidal flooding, tidal bores and probability of cyclone storms. Deficiency of P and toxicity of Fe and $\mathrm{Al}$ are the major constraints for crop cultivation in acid sulphate soil (Mukit, 2013). Similar findings were reported by Zaman et al. (2015), who found the tallest stevia plant from non-calcareous soil and the shortest from acid sulphate soil.

\section{Correlation between different physical parameters of A. vera}

Statistical relationships between growth, yield and yield attributes were studied. The correlation and regression lines of these parameters have been presented in Fig. 4.

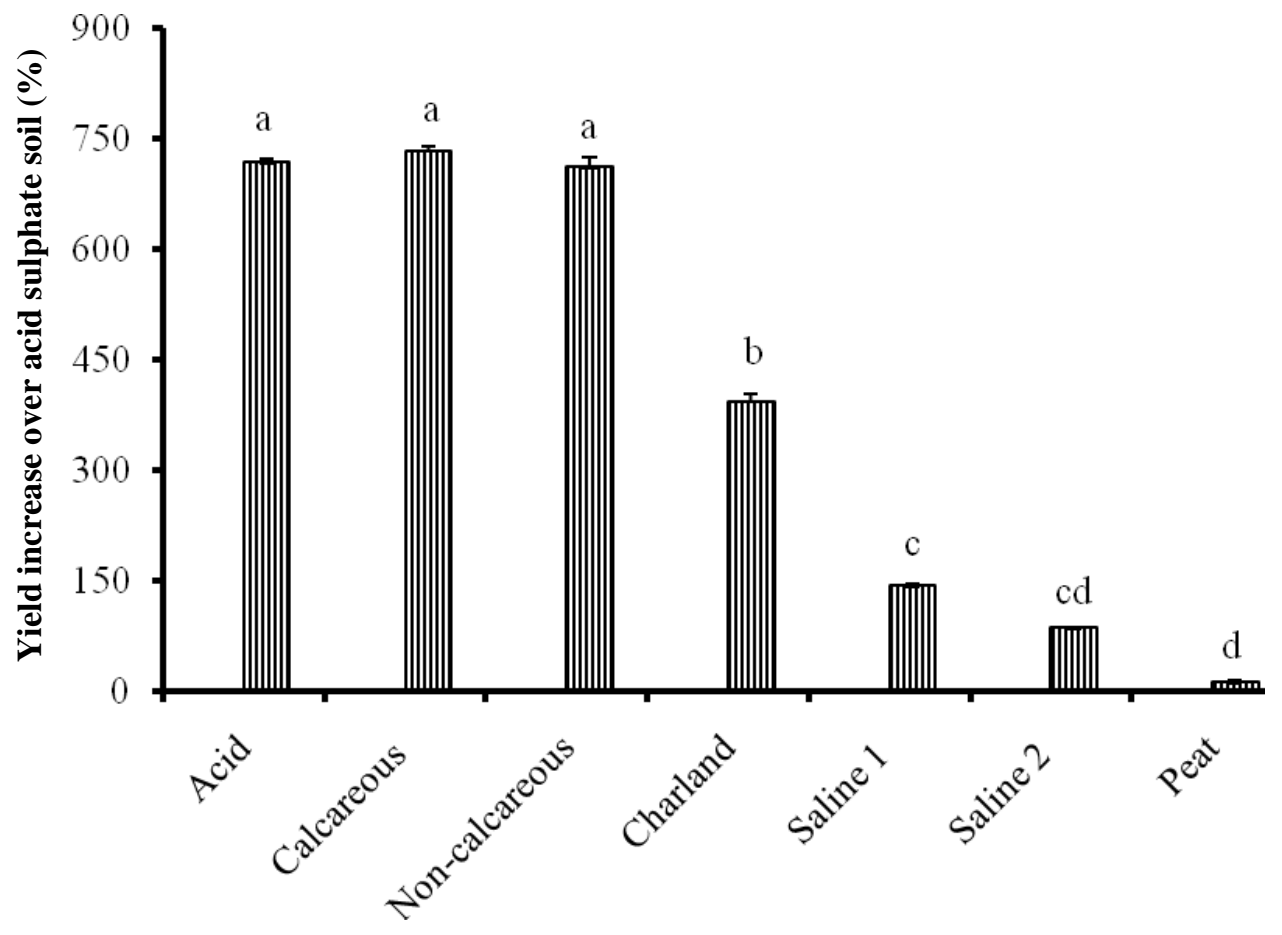

Soil types

Fig. 3. Yield increase over acid sulphate soil of Aloe vera grown in different soil types of Bangladesh $\left(\right.$ Saline $1=6.32 \mathrm{dS} \mathrm{m}^{-1}$ and Saline2 $=8.14 \mathrm{dS} \mathrm{m}^{-1}$ ) 

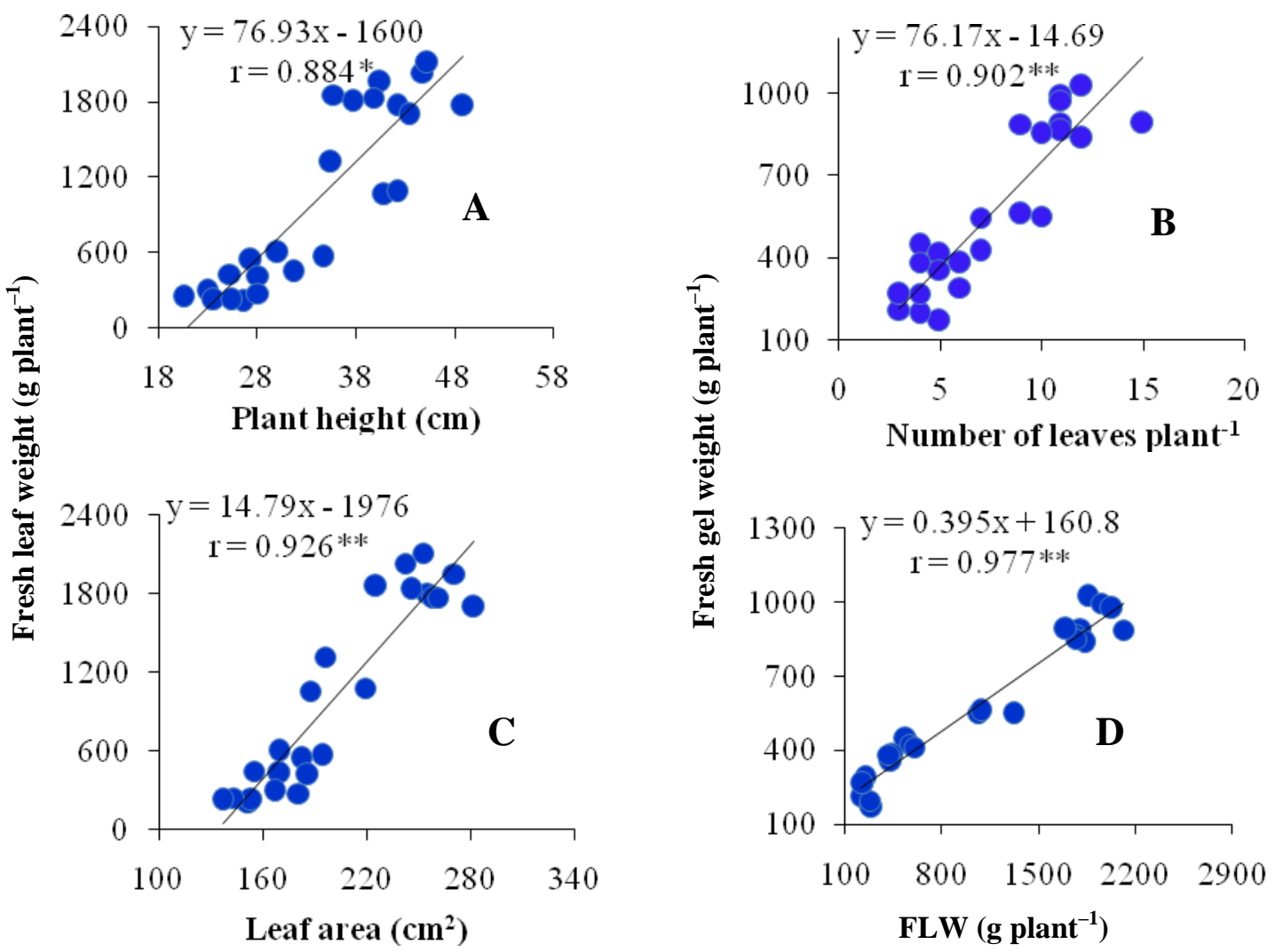

Fig. 4. Relationships between (A) plant height and FLW (B) number of leaves plant ${ }^{-1}$ and FGW (C) leaf area and FLW and (D) FLW and FGW of Aloe vera grown in different soil types of Bangladesh (FLW = Fresh leaf weight, FGW = Fresh gel weight)

The results revealed that the growth and yield parameters viz. plant height, number of leaves plant ${ }^{-1}$, mean leaf area, fresh leaf weight and fresh gel weight (g plant $^{-1}$ ) were significantly and positively correlated where correlation coefficients (r) were $0.884 *, 0.902 * *$, $0.926^{* *}$ and $0.977^{* *}$, respectively. The relationships were more evident from the regression equations $(\mathrm{y}=$ $76.93 \mathrm{x}-1600, \mathrm{y}=76.17 \mathrm{x}-14.69, \mathrm{y}=14.79 \mathrm{x}-1976$ and $\mathrm{y}=0.395 \mathrm{x}+160.8$, respectively) showing gradual increase in fresh leaf and gel weight with increasing plant height, number of leaves plant ${ }^{-1}$, leaf area and fresh leaf weight.

\section{Conclusion}

Aloe vera cultivation is expanding with the passage of time in different areas of the country as it provides quick and regular income to the farmers. The overall results of the study revealed that the growth and leaf gel yield of $A$. vera was significantly influenced by different soils types. In this study, among seven representative soil types, the calcareous soil displayed the best comprehensive performances in terms of the plant height, branch and leaf number, leaf area and fresh weight of leaves followed by those of non-calcareous and acid soils. The highest results of other growth parameters i.e., dry weight, gel weight of leaf and yield increase over acid sulphate soil was found in calcareous soil. In contrast, the lowest values of all the parameters were found in the plant grown in acid sulphate soil, which was at par with the plant grown in peat soil. The increase of dry leaf yield ranged from $12 \%$ in peat soil to $734 \%$ in calcareous soil over acid sulphate soil. The overall results suggest that farmers could be advised to grow A. vera either in calcareous or acid soils of Bangladesh. Since calcareous and non-calcareous soils are mostly used for growing cereals, pulses, cash crop like sugarcane, fruits etc, acid soil could be a better option for cultivating this important medicinal crop considering the socioeconomic conditions of the country.

\section{Acknowledgements}

The authors express their sincere thanks and gratitude to the concerned authority of Bangladesh Agricultural University Research System (BAURES), Mymensigh for financial support (Project No.: 2017/244/BAU). They also acknowledge the Aloe vera farmers of Shomvoganj, Mymensingh for their technical support.

\section{References}

Akamine, H., Hossain, M.A., Ishimine, Y., Yogi, K., Hokama, K., Iraha, Y. and Aniya, Y. 2007. Effects of application of N, P and $\mathrm{K}$ alone or in combination on growth, yield and curcumin content of turmeric (Curcuma longa L.). Plant Production Science, 10: 151-154. https://doi.org/10.1626/pps.10.15

Al-Humaid, A.I. 2005. Effects of compound fertilization on growth and alkaloids of datura (Datura innoxia Mill.) plants. Journal of Plant Nutrition, 27: 2203-2219. https://doi.org/10.1081/PLN-200034685 
Altieri, M.A. and Nicholls, C.I. 2003. Soil fertility management and insect pests: harmonizing soil and plant health in agroecosystems. Soil and Tillage Research, 72: 203-211. https://doi.org/10.1016/S0167-1987(03)00089-8

Atul, N.C., Santhosh, K.C., Bhattacharjee, C., Subal, D.K. and kKannan, K. 2011. Studies on immunomodulatory activity of Aloe vera (Linn). International Journal of Applied Biology and Pharmaceutical Technology, 2: 19-22.

BARC. 2005. Fertilizer Recommendation Guide, Soil publication No.45. Bangladesh Agricultural Research Council, Farm Gate, New Airport Road, Dhaka-1215.

Bashir, A., Saeed, B., Talat, Y.M., Jehan, N. 2011. Comparative study of antimicrobial activities of Aloe vera extracts and antibiotics against isolates from skin infections. African Journal Biotechnology, 10: 3835-3840.

Birkhofer, K., Bezemer, T.M., Bloem, J., Bonkowski, M., Christensen, S., Dubois, D., Ekelund, F., Fließbach, A., Gunst, L., Hedlund, K., Mäder, P., Mikola, J., Robin, C., Setälä, H., Tatin-Froux, F., Van der Putten, W.H. and Scheu, S. 2008. Long-term organic farming fosters below and aboveground biota: implications for soil quality, biological control and productivity. Soil Biology and Biochemistry,40:22972308.https://doi.org/10.1016/j.soilbio.2008.05.007

Borra, S.K., Lagisetty, R.K. and Mallela, G.R. 2011. Anti-ulcer effect of Aloe vera in non-steroidal anti-inflammatory drug induced peptic ulcers in rats. African Journal of Pharmacy and Pharmacology, 5(16): 1867-1871.

Boudreau, M.D. and Beland, F.A. 2006. An evaluasion of the biological and toxicological propertis of Aloe barbadensis Mill and Aloe vera. Journal of Environmental Science and Health, 24 (1): 153-158.

Broadley, M., Brown, P., Cakmak, I., Ma, J.F., Rengel, Z. and Zhao, F. 2012. Beneficial elements. In P. Marschner (eds), Marschner's Mineral Nutrition of Higher Plants, 3rd Edn. pp. 249-269. Acadenic Press, USA. https://doi.org/10.1016/B978-0-12-384905-2.00008-X

Chandan, B.K., Saxena, A.K., Shukla, S., Sharma, N., Gupta, D.K., Suri, K.A., Suri, J., Bhadauria, M. and Singh, B. 2007. Hepatoprotective potential of Aloe barbadensis Mill. against carbon tetrachloride induced hepatotoxicity. Journal of Ethnopharmacology, 111: 560-566. https://doi.org/10.1016/j.jep.2007.01.008 PMid: 17291700

Chiarini, L., Bevivino, A., Dalmastri, C., Nacamulli, C. and Tabacchioni, S. 1998. "Influence of plant development, cultivar and soil type on microbial colonization of maize roots. Applied Soil Ecology, 8: 11-18 https://doi.org/10.1016/S0929-1393(97)00071-1

Chowdhury, A.H.M.R.H., Rahman, G.M.M., Saha, B.K. and Chowdhury, M.A.H. 2008. Addition of some tree leaf litters in forest soil and their effect on the growth, yield and nutrient uptake by red amaranth. Journal of Agroforestry and Environment, 2: 1-6.

Dange, E., Bisrat, D., Viljoen, A., Van Wyk, B.E. 2000. Chemistry of Aloe species. Current Organic Chemistry, 4: 1055-1078. https://doi.org/10.2174/1385272003375932

Darini, M.T.H., Indradewa, D, Shiddieq, D. and Purwantoro, A. 2013. Response growth and Aloe vera contains aloin explant plantlets from different sources. AgroUPY. Journal of Science, 4(5): 5-12.

Egamberdiyeva, D. 2007. The effect of plant growth promoting bacteria on growth and nutrient uptake of maize in two different soils. Applied Soil Ecology, 36: 184-189. https://doi.org/10.1016/j.apsoil.2007.02.005

Garg, J. and Kumar, A. 2012. Effect of different soil types on growth and productivity of Euphorbia lathyris L. A hydrocarbon yielding plant. International Journal of Life science and Pharma Research, 2: 164-173.

Gomez, K.A. and Gomez, A.A. 1984. Statistical Procedures for Agricultural Research. 2nd Edn., pp. 207-215. John Wiley \& Sons. Inc. New York. PMid:6476466

Hamman, J.H. 2008. Composition and applications of Aloe vera leaf gel. Molecules, 13: 1599-1616. https://doi.org/10.3390/molecules 13081599 PMid:18794775 PMCid:PMC6245421

Hawkesford, M., Horst, W., Kichey, T., Lambers, H., Schjoerring, J., Skrumsager, M. and White, P. 2012. Functions of macronutrients. In P. Marschner (eds), Marschner's mineral nutrition of higher plants, 3rd Edn. pp. 135-189. Academic Press, USA. https://doi.org/10.1016/B978-0-12-384905-2.00006-6

Hossain, M.A. and Ishimine, Y. 2005. Growth, yield and quality of turmeric (Curcuma longa L.) cultivated on dark-red soil, gray soil and red soil in Okinawa, Japan. Plant Production Science, 8: 482-486.https://doi.org/10.1626/pps.8.482

Hossain, M.A., Yamanishi, M., Yara, T., Chibana, S., Akamine, H. and Tamaki, M. 2011. Growth characteristics, yield and mineral content of redflower ragleaf (Crassocephalum crepidioides (Benth.) S. Moore) at different growth stages, and in dark-red soil, red soil and gray soil in Okinawa. Science Bulletin of the Faculty of Agriculture, University of the Ryukyus, 58: 1-11.

Hossain, M.A., Akamine, H., Nakamura, I. and Tamaki, M. 2012. Effects of N, $\mathrm{P}$ and $\mathrm{K}$ on growth characteristics of redflower rag leaf (Crassocephalum crepidioides). Science Bulletin of the Faculty of Agriculture, University of the Ryukyus, 59: 13-18.

Islam, M.M., Karim, A.J.M.S., Jahiruddin, M., Majid, N.M., Miah, M.G., Ahmed, M.M. and Hakim, M.A. 2011. Effects of organic manure and chemical fertilizers on crops in the radish-stem amaranth-indian spinach cropping pattern in homestead area. Australian Journal of Crop Science, 5: 1370-1378.

Jones, K. 2007. Dietary Aloe vera supplementation and glycemic control in diabetes. Diabetes, 6-9.

Josias, H.H. 2008. Composition and Applications of Aloe vera Leaf Gel. Molecules, 13:1599-1616. https://doi.org/10.3390/molecules 13081599 PMCid:PMC6245421

Khan, M.S., Rahman, M.M., Begum, R.A., Alam, M.K., Mondal, A.T.M., Islam, A.I. and Salahin, M.S. 2008. Problems soil of Bangladesh, Soil science publication, 8:4. Soil Science Division, Bangladesh Agriculture Institute, Porana Palton, Dhaka.

Khanom, S., Chowdhury, M.A.H., Islam, M.T. and Saha, B.K. 2008. Influence of organic and inorganic fertilizers on mineral nutrition of Stevia in different types of soil. Journal of the Bangladesh Agricultural University, 6: 27-32.

Kumar, S. and Yadav, J.P. 2014. Ethnobotanical and pharmacological properties of Aloe vera: A review. Journal of Medicinal Plant Research, 8(48): 1387-1398.

Latour, X., Corberand, T., Laguerre, G., Allard, F. and Lemanceau, P. 1996. The composition of Flourescent Pseudomonad population associated with roots is influenced by plant and soil type. Applied and Environmental Microbiology, 62: 2449-2456. PMid:16535355 PMCid:PMC1388893

Liu, Y., Zhang, Z.S., He, Y.L., Zhang, B.G. and Li, X.E. 2007. Quality of crude traditional Chinese drugs and ecological environment. Modernization of Traditional Chinese Medicine and Materia Materia-World Science and Technology, 9: 65-69.

Li, Q.L. and Xiao, H.L. 2012. The interactions of soil properties and biochemical factors with plant allelopathy. Ecology and Environmental Sciences, 21: 2031-2036.

Lützow, M.V., Kögel-Knabner, I., Ekschmitt, K., Matzner, E., Guggenberger, G., Marschner, B. and Flessa, H. 2006. Stabilization of organic matter in temperate soils: mechanisms and their relevance under different soil conditions - a review. European Journal of Soil Science, 57: 426-445.https://doi.org/10.1111/j.1365-2389.2006.00809.x

Manvitha, K. and Bidya, B. 2014. Aloe vera: A wonder plant its history, cultivation and medicinal uses. Journal of Pharmacognosy and Phytochemistry, 2(5): 85-88.

McKeown, E. 1987. Aloe vera. Cosmetic and Toiletries, 102: 64-65.

Mevi-Schütz, J., Goverde, M. and Erhardt, A. 2003. Effects of fertilization and elevated $\mathrm{CO} 2$ on larval food and butterfly 
nectar amino acid preference in Coenonympha pamphilus L. Behavioral Ecology and Sociobioligy, 54: 36-43. https://doi.org/10.1007/s00265-003-0601-8

Miladi, S. and Damak, M. 2008. In vitro antioxidant activities of Aloe vera leaf skin extracts. Journal de la Société Chimique de Tunisie, 10: 101-109.

Moorthy, S.K. and Malliga, P. 2012. Plant characteristics, growth and leaf gel yield of Aloe barbadensis Miller as affected by cyanopith biofertilizer in pot culture. International Journal of Civil and Structural Engineering, 2(3): 884.

Mukit, M.R. 2013. Agripedia series, Agri-career, 3rd Edn. The Network Scientific Publication, Dhaka. pp. 162-163.

Naveena, Bharath, B.K., Selva, S. 2011. Antitumor activity of Aloe vera against Ehrlich Ascites Carcinoma (EAC) in Swiss albino mice. International Journal of Pharma and Bio Sciences, 2: 400-409.

Ohshiro, M., Hossain, M.A., Nakamura, I., Akamine, H., Tamaki, M. Bhowmik, P.C. and Nose, A. 2016. Effects of soil types and fertilizers on growth, yield, and quality of edible Amaranthus tricolor lines in Okinawa, Japan. Plant Production Science, 19(1): 61-72. https://doi.org/10.1080/1343943X.2015.1128087

Okonkwo, B.O. Ejema, O.P. and Ofudu, P.K. 2009. Aloe vera: Medicinal power plant. J. K. publishers Enugu, Nigeria. p. 37.

Orcutt, D.M. and Nilsen, E.T. 2000. Physiology of Plants under Stress: Soil and Biotic Factors. John Wiley \& Sons, Inc. New York.

PMCid:PMC102418
Pineda, A., Zheng, S.J., Van Loon J.J.A., Pieterse, C.M.J. and Dicke, M. 2010. Helping plants to deal with insects: the role of beneficial soil-borne microbes. Trends Plant Science, 15: 507-514.https://doi.org/10.1016/j.tplants.2010.05.007 PMid:20542720

Rahi, T.S., Singh, K. and Singh, B. 2013. Screening of sodicity tolerance in Aloe vera: an industrial crop for utilization of sodic lands. Industrial Crops and Products, 44: 528533.https://doi.org/10.1016/i.indcrop.2012.10.001

Sripontan, Y., Hung, M.H., Young, C.C. and Hwang, S.Y. 2014. Effects of soil type and plant growth promoting microorganism on cabbage and Spodoptera litura performance. Journal of Agriculture and Forestry, 63(3): $153-161$.

Surjushe, A., Vasani, R. and Saple, D.G. 2008. Aloe vera: A short review. Indian Journal of Dermatology, 53(4): 163-166. https://doi.org/10.4103/0019-5154.44785 PMid:19882025 PMCid:PMC2763764

Yusuf, S., Abdulkarim, A. and Mshelia, D. 2004. Effects of Aloe vera on gastric acid secretion and acute gastric mucosal injury. Journal of Ethnopharmacology, 93: 33-37. https://doi.org/10.1016/j.jep.2004.03.027 PMid:15182901

Zaman, M.M., Chowdhury, M.A.H. and Chowdhury T. 2015. Growth parameters and leaf biomass yield of stevia (Stevia rebaudiana, Bertoni) as influenced by different soil types of Bangladesh. Journal of the Bangladesh Agricultural University, 13(1): 31-37. https://doi.org/10.3329/jbau.v13i1.28708 